information for the Management Board to assess whether the student has the required academic standard for entry to the School. It is expected that all students will be physies or engineering graduates or else have had considerable theoretical and practical experience in at least one branch of science or engineering. Mathematics up to subsidiary degree standard is necessary, particularly for the reactor physics lectures. The fee of $£ 250$ for the course does not include hotel accommodation; but the school is prepared to book hostel, hotel or guest-house places for students as available.

\section{Fourteenth International Horticultural Congress, Scheveningen}

THE Fourteenth International Horticultural Congress will be held in The Netherlands at Scheveningen during August 29-September 6, 1955. Prior to the Congress, during August 25-27, excursions will be made to scientific institutions and to horticultural districts in The Netherlands. The Congress will consider vegetables and seeds; fruits; flowers and flower bulbs; trees, shrubs and perennials; and tropical and subtropical horticulture and plantation crops. Within each of these sections the following will be discussed : plant breeding and propagation; soils, fertilizers and water supply ; plant diseases and pests; environment; and horticultural engineering, technology and technical marketing problems. Twenty minutes will be allowed for reading each paper, with ten minutes for discussion. The language may be English, French or German. The fee for membership of the Congress is 60 guilders (which includes a copy of the proceedings) or 25 guilders for an associate member. Application for membership should be sent to the Secretary of the Congress, Dr. G. de Bakker, Ministry of Agriculture, 30 Bezuidenhout, The Hague, from whom further information can be obtained.

\section{Announcements}

ThE Cornmittee of Privy Council for Medical Research, after consultation with the Medical Research Council and with the president of the Royal Society, has appointed Prof. A. Bradford Hill, professor of medical statistics in the University of London, Prof. G. F. Marrian, professor of chemistry in relation to medicine in the University of Edinburgh, and Prof. G. W. Pickering, professor of medicine in the University of London, to be members of the Medical Research Council; it has also appointed the Honourable Richard Frederick Wood, M.P., to be a member.

The André Dreyfus Foundation has awarded the Dreyfus Prize for 1954 to Dr. Hans Kalmus, of the Galton Laboratory, University College, London. Dr. Kalmus intends to use his prize spending a semester (April-September 1955) in Brazil, working on problems of human genetics.

THE Perkin Medal of the Society of Dyers and Colourists has been awarded to Dr. Arthur Zitscher for his work leading to the discovery of the new class of azoic dyes based on the arylamides of $o$-hydroxycarboxylic acids. The presentation will be made at a meeting of the Society to be held in the University of Manchester on October 15, when Dr. Zitscher will deliver a lecture on his work.

The Textile Institute Medal has been awarded to Sir Ernest Goodale, president of the Institute during
1939-40 and chairman of the Institute's London Section during 1950-52; the Medal was inaugurated in 1921 to mark distinguished services to the industry in general and to the Textile Institute in particular. The Warner Memorial Medal, awarded in recognition of outstanding work in textile science and technology, has been awarded to Mr. R. Meredith, of the College of Technology, Manchester.

THE Scientific Instrument Manufacturers' Association is arranging an exhibition of electronic aids to production, design and research, under the title "Electronics at Work", to be held in the Chamber of Commerce Hall, Birmingham, during November 23-25. Admission is by ticket obtainable free on request from the Association at 20 Queen Anne Street, London, W.1, or from tho Birmingham Chamber of Commerce, the Birmingham Exchange and Engineering Centre, or the Information Department, Birmingham.

THE Spectroscopic Panel of the Hydrocarbon Branch of the Institute of Petroleum is arranging a conference on "Molecular Spectroscopy", to be held in the Institution of Electrical Engineers, Savoy Place, Victoria Embankment, London, W.C.2, during October 28-29. Further information can be obtained from G. N. Ross, Anglo-Iranian Oil Co., Ltd., Chertsey Road, Sunbury-on-Thames, Middlesex.

A SECOND edition of the "Departmental Handbook" of the New Zealand Department of Scientific and Industrial Research (pp. 68. Wellington: Government Printer, 1954) has been necessitated by departmental reorganization, staff changes and the heavy demand for the first edition. The bulk of the Handbook is given to brief descriptions of the various Divisions, Laboratories, Sections, etc., of the Department, with lists of staff and also the incorporated research associations. These are supplemented by notes on the general organization and administration of the Department, its activities and responsibilities and development, with details of committees and an index. The Handbook is illustrated and is well produced.

THE twenty-first annual Christmas symposium of the Division of Industrial and Engineering Chemistry of the American Chemical Society will be held during January 7-8, 1955, the subject being "Pulsatory and Vibrational Phenomena". The symposium will be broad in scope, with papers on the following subjects : shock phenomena; pulse extraction and other vibration devices in chemical engineering process operations; generation and effects, both physical and chemical, of ultrasonic vibrations; vibration problems in combustion; vibration effects on structures and structural materials; and highfrequency heating. Those intending to participate should write to the programme chairman, DeWitt O. Myatt, Atlantic Research Corporation, $901 \mathrm{~N}$. Columbus Street, Alexandria, Virginia.

Erratum. Mr. R. Persson states that in his communication entitled "Measurements on the Neutron Multiplication in a System of Uranium Rods and Ordinary Water", published in Nature of August 7, p. 265 , the results obtained from formula (4) should be corrected for the diffusion of slow neutrons from the reflector to the core. This correction is important, especially for the most compact lattices, and the experimental points are then in much better agreement with the theoretical curve. 